\title{
Social-ecological memory as a source of general and specified resilience
}

\author{
Björn Nykvist $^{1,2}$ and Jacob von Heland ${ }^{1}$
}

\begin{abstract}
We explored why social-ecological memory (SEM) is a source of inertia and path dependence, as well as a source of renewal and reorganization in social-ecological systems (SESs). We have presented two case studies: the historical case of the Norse settlement on Greenland and an empirical case from contemporary southern Madagascar. The cases illustrate how SEM is linked to specific pathways of development and a particular set of natural resource management practices. We have shown that in each case, a broader diversity of SEM is present in the SESs, but not drawn upon. Instead, SEMs are part of what explains community coherence and the barriers to adoption of more diverse practices. We have elaborated on how specific SEMs are linked to specified resilience, and we have shown that this fits existing notions of resilience, robustness, inertia, and path dependence. We have proposed that to change the dynamics of development pathways that do not produce desired results, it is necessary for managers to shift from specific to general SEM, which would also mirror the shift from specified to general resilience. The challenge lies in the interplay between the specified and the general. In this critical work, it is important to recognize that the valued diversity of SEM necessary for general resilience might actually reside in a different community.
\end{abstract}

Key Words: general and specified resilience; identity; pathway dependency; robustness; social-ecological memory

\section{INTRODUCTION}

Societal responses to environmental change, such as adaptations to climate change (Adger 2006) or adaptive strategies for management of natural resources (Allison and Hobbs 2004, Armitage et al. 2009), constitute an important area of sustainability science (Kates et al. 2001). In this regard, insights from research on resilience find that it is important to identify and nurture "sources of resilience" (Folke et al. 2005) to manage social-ecological systems (SESs) along desired pathways of development (Folke et al. 2010). Such sources of resilience are described as creating capacity in an SES to cope with, adapt to, and shape the system under uncertainty and surprise. It is suggested that possessing sources of resilience is desirable for decision makers involved with governing SESs, and such resilience is referred to in the literature as social-ecological resilience, or general resilience (Walker and Salt 2006). Pursuing an SES development pathway, general resilience is the "resilience of any and all parts of a [social-ecological] system to all kinds of shocks, including novel ones" (Folke et al. 2010). In contrast, specified resilience concerns "some particular part of a system, related to a particular control variable, to one or more identified kinds of shocks" (Folke et al. 2010).

Social-ecological memory (SEM), defined as the accumulated experiences and history of ecosystem management collectively held by a community in an SES (Barthel et al. 2010), is described as one such source of resilience to nurture and draw from in adaptive governance of SESs (Folke et al. 2005). SEM provides adaptive capacity that enhances and builds resilience (DavidsonHunt and Berkes 2003a, Olsson et al. 2004, Barthel et al. 2005, 2010, Berkes and Seixas 2005, Galaz et al. 2008). However, memory is undoubtedly a process that "stores" and "forgets" all types of information. In addition, maladaptive resource management practices that lead to degradation of natural resources or higher vulnerability must somehow be stored and remembered; the social processes of learning and memory cannot be "intrinsically benevolent" (e.g., Wenger 1998:132) or a panacea for ecosystem management (Barthel et al. 2010). In this sense, the literature has also linked memory to undesirable outcomes, e.g., traps, path dependency, inertia, and rigidity (Costanza 1987, Gunderson et al. 1995, Galaz 2005, Gunderson and Light 2006, Robards et al. 2011). This might be called undesirable resilience (see, e.g., Scheffer et al. 2001, Folke 2006) and constitutes the very problems that adaptive governance should overcome (Dietz et al. 2003, Folke et al. 2005, Fabricius et al. 2007). In other words, the literature of SEM has not properly addressed the question of what resilience SEM nurtures (Carpenter et al. 2001).

We conclude that the literature on resilience hence gives two different descriptions of the role of social memories in management. On one hand, it is suggested as a desirable source of renewal, innovation, and reorganization. On the other, it is suggested as an undesirable source of traps, rigidity, inertia, and path dependency. Few studies of resilience have, however, explicitly addressed how SEM is linked to both these aspects of social memories. No studies have explored the implications of how SEM nurtures different forms of resilience in SESs. Therefore, we ask the following: What are the mechanisms by which SEM gives rise to both desirable renewal and innovation on the one hand, and rigidity, inertia, and path dependency on the other? What theory development is needed to incorporate these different roles of SEM coherently in resilience thinking?

In relation to our first research question, we describe the mechanism through which SEM is said to build desirable socialecological resilience. We provide more detail on how and why SEM can be said to be part of path dependency in communitybased natural resource management. This is done by drawing on the historical and archaeological material of the Norse Greenlanders, and a case study about the Tandroy natural resource management in southern Madagascar that combines fieldwork with literature studies. We do not view SEM as the only factor explaining inertia and path dependency, nor is our purpose to explain the unfolding of resource use in the two cases per se. Instead, the cases illustrate how SEM is one lens that can be used 
to understand the reluctance to change natural resource management practices. In analyzing and discussing these results, we provide one answer to the second question by suggesting that the theory needs to recognize that specific SEMs nurture specified resilience and that getting at general resilience requires drawing from a diversity of specified SEMs. We discuss how this relates to the critical issue of always asking in SES research the question, resilience of what? We conclude with reflection on how general resilience and general SEM should be interpreted in contemporary natural resource management.

\section{THEORY}

Folke et al. (2005:444) coined the term "social sources of resilience" to point to a wide array of social features, including social capital, social networks, and memory, which in many cases have seemed to enable diversity, renewal, reorganization, and innovation in SESs during phases of disturbance and change (see also Galaz et al. 2008, Hahn et al. 2008, Norberg and Cumming 2008). Studies about SEM in natural resource management concern the knowledge, experience, and practice required to manage an ecosystem and its dynamics, as well as how this knowledge is stored, modified, and transmitted among a group of people through time (Folke et al. 2003, Folke 2006, Barthel 2008, Barthel et al. 2010, Tidball et al. 2010).

SEM is the accumulated set of diverse experiences in a community that have come about as human groups live in a shared environment for a long time (cf. Davidson-Hunt and Berkes 2003a). In the literature, the diversity of SEMs residing in groups that live in SESs is described as providing insurance capacity, i.e., the potential for alternative ways to maintain important functions when faced with change (Folke et al. 2003). This idea is analogous to response diversity in systems ecology, meaning that ecosystems with a diversity of functional groups, and species in those groups, have a better capacity to respond to disturbances and persist because key functions will be retained even if some species and groups decline (Elmqvist et al. 2003). The idea has also been supported by complex adaptive systems theory, in which diversity in a general sense allows for the SES to have several alternatives to handle disturbance, uncertainty, and surprise, i.e., either to persist or to make space for reorganization, renewal, and novelty (Norberg and Cumming 2008). Through these qualities, SEM is proposed to nurture resilience of SESs (Folke et al. 2005).

The study by Fikret Berkes (1998) of the James Bay Cree is a classic example of research on SEM. Through an intergenerational engagement with the natural resources and ecosystem dynamics, the Cree developed extensive and collectively held memory about gradual long-term and large-scale ecological dynamics stored among the elders. When ecological conditions changed, the community adapted its livelihood practices. The oral memory, which conveyed "old memories" anew, proved critical because sense making resulted in successful adaptations of natural resource management practices.

\section{METHODS}

We investigate the relationship between SEM and social-ecological resilience with a mechanism-based approach (Hedström and Swedberg 1998, Hedström and Ylikoski 2010). The purpose of this approach is not only to make explicit the covariance between two variables, but also to explore and unveil the mechanisms by which this relationship forms (Hedström and Swedberg 1998), to better explain causation (Hedström and Swedberg 1998). We explore social mechanisms, and the purpose is to assess the congruence between two variables with a stated relationship and covariance, aiming to refine theory (George and Bennet 2005). That is, there needs to be a social mechanism that explains how a diversity of SEM nurtures social-ecological resilience in SESs. Through our two case studies, we illustrate how a diversity of SEM in SESs is not necessarily drawn on and how SEM nurtures resilience of different sets of natural resource management practices. Based on these findings, we discuss how it cannot simply be a mechanism that links SEM and social-ecological resilience. In addition, SEM is also part of a different mechanism, which indeed explains path dependency.

We analyze two case studies. In each case, we contrast two communities with different management practices and memories living in the same SES. The aim is not to provide management recommendations or to make comparisons between the two cases. Rather, emphasis lies in contributing to theory development, testing, and improving the understanding of how SEM nurtures resilience. We use the two cases with different methodologies to increase our understanding of the relationships between SEM and the resilience of development pathways in an SES. Both cases have been researched, discussed, and referred to in the SES literature (Kinzig et al. 2006, Elmqvist et al. 2007, Scheffer and Westley 2007, Tengö et al. 2007, Scheffer 2009). In both cases, local ecosystem dependence for livelihood subsistence is high. Both cases have been suggested to undergo gradual environmental change, increasing the vulnerability of their specific pathway for well-being, suggesting the need for further societal adaptation or transformation.

\section{The Norse case study}

The first case study method is a review of secondary historical and anthropological data found in the literature on the Norse Greenland settlement (Fig. 1, Table 1). The Norse Viking colony on Greenland between late AD 900 and mid-1400 has been the object of research in a range of disciplines since the 19th century (e.g., Utterström 1955, McGhee 1984, Vail 1998, Gulløv 2008). Although we do not present original data, the methodology of using secondary data to understand the mechanism of how SEM influences resilience is warranted because this case has been referred to in the literature on SES and described as lacking resilience and the ability to adapt to a changing climate (Davidson-Hunt and Berkes 2003b, Scheffer 2009). We review the available secondary data and analyze the key components of the Norse and Inuit SEMs on Greenland, and the interactions and cultural exchange between these two communities, to cast light on the different mechanisms with which SEM builds resilience.

\section{The Tandroy case study}

The second case study presents empirical research on the climatically vulnerable Tandroy clan society in the south of Madagascar (Fig. 1, Table 1; Heurtebize 1986, Dostie et al. 2002). The Tandroy case study builds on fieldwork during a sixth-month period, divided into two visits in 2005 and 2006. Fieldwork took place in three coastal and three noncoastal clans. Our methodology included interviews and participatory observation, and the description and quotes we have presented correspond with findings thematically analyzed in the data set as a whole 
Table 1. The two social-ecological case studies: Greenland between late AD 900 and mid-1400 and contemporary Androy, Madagascar.

\begin{tabular}{llll}
\hline \hline $\begin{array}{l}\text { Social-ecological } \\
\text { system }\end{array}$ & Type of case & $\begin{array}{l}\text { Natural resource management } \\
\text { communities }\end{array}$ & Selection of references \\
\hline AD 985 to 1450 Greenland & Historical case & $\begin{array}{l}\text { The Norse } \\
\text { The Inuit }\end{array}$ & $\begin{array}{l}\text { McGovern 1994, Buckland et al. 1996, } \\
\text { Diamond 2005, Berglund 2010 }\end{array}$ \\
$\begin{array}{l}\text { Contemporary Androy, } \\
\text { Southern Madagascar }\end{array}$ & Empirical Case & $\begin{array}{l}\text { The Tandroy } \\
\text { The Vezo }\end{array}$ & $\begin{array}{l}\text { Heurtebize 1986, Astuti 1995, Middleton } \\
\text { 1997, Fee 2000 }\end{array}$ \\
\hline
\end{tabular}

(Lofland and Lofland 1984). A more complete description and analysis of the data is found in von Heland (2011) and von Heland and Folke (2014). The research emphasized Tandroy natural resource management and its relationship to the ocean and fishing. In rural Androy, elders have a mandate to represent their clans in accordance with ancestral customs and laws (lilandrazana), and interviews were conducted with clan elders who in turn suggested other people in the community. Additional interviews were carried out with the head of the fishing department office in Ft. Dauphin, a lobster company in Ft. Dauphin, a fish harvest collector with a car, fisher middle-hands, fishermen, and representatives from fishing associations (see Appendix 1).

Fig. 1. The two social-ecological case studies: Greenland between late AD 900 and mid-1400 and contemporary Androy, Madagascar.

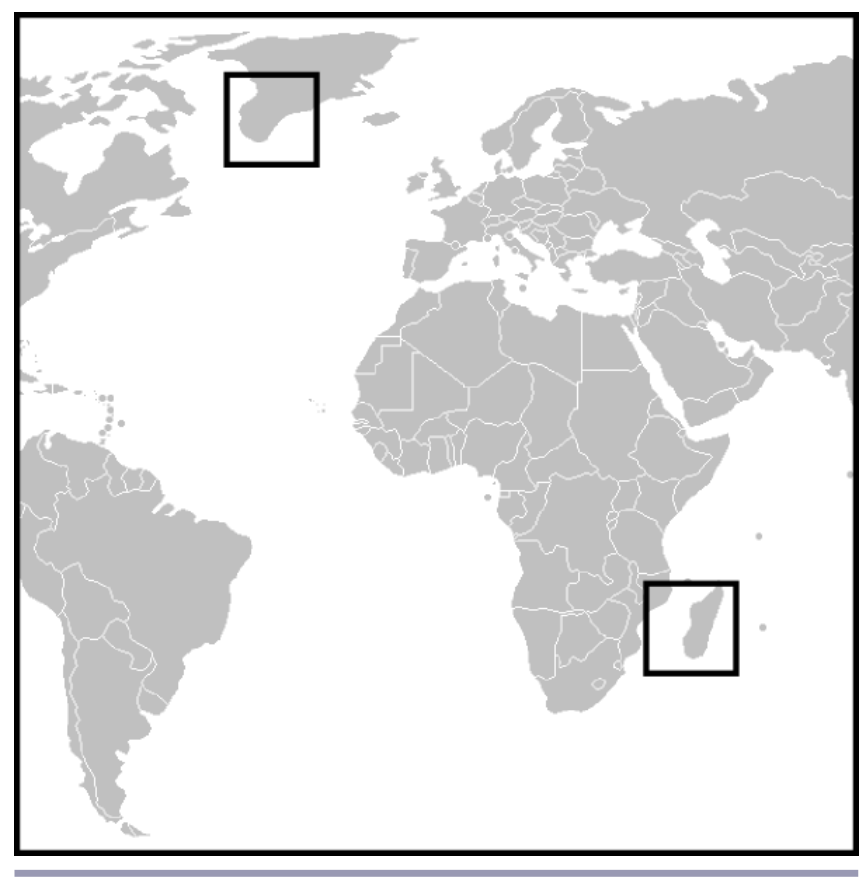

\section{RESULTS}

Case study 1: the Norse in Greenland

The rise and fall of the Norse settlements on Greenland between late AD 900 and 1450 has been the subject of intensive research (e.g., Berglund 2010). A range of explanatory factors and theories as to their decline exist, but there is general agreement around three key factors: decreased trade and contact with the European continent, climate change during the Little Ice Age, and limited cultural exchange and learning between Norse and local Inuit communities (McGovern 1980, Pringle 1997, Berglund 2010). The Norse diaspora that permanently settled on Greenland at the end of the 10th century was headed by Norwegian-born Erik the Red who brought Icelandic Norsemen hoping for green and arable land in plenty (Olson and Bourne 1906, cf. Blom 1973). They established two settlements deep within the southwestern fjords (McGovern 1980). These sheltered pockets with pastures were sites for farmsteads with dairy farming for about 5000 people (McGovern 1979, Gauthier et al. 2010). The Scandinavian ways of farming were rather ill-adapted to meet conditions on Greenland. The Norse brought crops and livestock and went through painstaking efforts to keep the livestock alive and the land farmable despite the short growing season and the meager soils (Berglund 2010). Wheat and barley were considered too difficult to grow. Pigs were also found to be impossible to keep, and seaweed was used as fodder to feed the cattle during wintertime. Dairy farming was less rewarding than in Scandinavia, and the farmstead economy also relied increasingly on collectively organized seasonal hunting for caribou, seal, and seabirds (Buckland et al. 1996, Berglund 2010).

Whether the Norse relied substantially on fishing is disputed (Berglund 2010). However, archaeologists have noted that Greenland's bioarchaeological conditions provide a wellpreserved archeofauna, and the fact that fish bones have been rarely found (e.g., Buckland et al. 1996) have led some to conclude that fishing was not a prominent practice (Perdikaris and McGovern 2008).

The adaptation of livelihoods also involved transoceanic journeys. Timber was scarce on Greenland, and seasonal logging voyages were made westward to North America. In the other direction, the Norse settlements on Greenland kept an active trade network with Iceland and continental Europe (Dugmore et al. 2007). The Greenlanders converted to Christianity at the beginning of the 11th century (Olson and Bourne 1906, Diamond 2005) and sent $635 \mathrm{~kg}$ of walrus ivory to Rome in year AD 1327 to pay the Crusade tax (McGovern 1980, 1990). The Greenlanders adapted to changes in Europe in everything from clothing fashions to church art and imperial politics (McGovern 1994).

The Little Ice Age made climate conditions harsher on Greenland from the beginning of the 1400s. Gradually (Dugmore et al. 2007, Berglund 2010), or more dramatically (Diamond 2005), the Norse subsistence became less viable. Trade contacts with Europe had also decreased, and the last trading ship visited Greenland in the 
1360s (McGovern 1994). By the early 15 th century, the Norse society was in decline and eventually disappeared.

Whether climate change or unfavorable economic changes and declining trade networks with Europe (Dugmore et al. 2007) were most important are not the main issues studied in this case. Instead, from a natural resource management perspective, the intriguing question is, why did the Norse not shift their pathway of development and resource use? More specifically, why did they not learn from the SEM of the Thule Inuit who resided in the same SES for 300 years (McGovern 1994, Buckland et al. 1996)?

The Inuit were seasonal and mobile pastoralists who adapted to the changing climate. Their resource management practices involved hunting seals and whales with specialized technology including harpoons, kayaks (Berglund 2010), and ice drills for ring seal hunting at breathing holes the Inuit made in the ice (Perdikaris and McGovern 2008). The mobility of their settlements enabled them to adapt to environmental variables such as climate change and movement in whale and seal populations (McGovern 1994). Using Norse and Inuit sagas and church records, medieval scholars have studied the contact between Norse and Inuit people in ancient settlements and hunting outposts. Although a recent publication has suggested that the Norse and the Inuit coinhabited Sandhavn between the 1200 s and 1300 s, with the possibility of a trade-driven relationship (Golding et al. 2011), most studies suggest that there was very little contact and exchange, i.e., cultural and material, between the groups, with some reports of conflicts and killings (McGovern 1980, 1990, McGhee 1984, Gulløv 2008, Gauthier et al. 2010). Most evidence hence points in the direction of two different kinds of subsistence communities with different organization, practices, and SEMs (McGovern 1994, Pringle 1997). The literature offers descriptions of the Norse as "culturally conservative" (Dugmore et al. 2007:14), in the sense of having a high barrier to influence from other cultures. We conclude that the two communities in all likelihood had two very different cultures and sets of SEMs.

The Norse saw themselves as living on the periphery of the Christian civilizations and regarded the Inuit and their shamanistic beliefs as primitive and inferior (McGovern 1980, 1990). According to accounts of early encounters, the Inuit "didn't start bleeding until they were dead" (Gulløv 2008:21), and they were believed to be an inferior human race and given the name skrälingar, a pejorative category referring to the Inuit as troll-like beings (McGovern 1994, Gulløv 2008). In this light, it seems possible to suggest that because the Thule Inuit were regarded as different and with inferior practices, the Norse did not adopt practices such as hunting for ring seal and whales. The Inuit's sophisticated technology of traveling by kayaks and hunting with harpoons was unique. This would have been apparent if the Norse had drawn from the Thule Inuit memory, imitated them, and socially learned from them in Bandura's (1977) sense of social learning. These would have been acts that symbolically recognized the value of Inuit skills and technology. They would have been acts that blurred the division between the two societies that the Norse tried hard to keep intact. It is of course difficult to prove that SEM per se was explicitly part of downgrading other natural resource management practices. However, if one defines SEM as the socially accumulated knowledge, experiences, and practices of how to manage natural resources, then one can conclude that SEM was an integral part of the social structures and part of a mechanism explaining the path dependency of the Norse community. In the same way that the literature has linked memory to undesirable outcomes in the old management paradigm, e.g., traps, path dependency, inertia, and rigidity (Costanza 1987, Gunderson et al. 1995, Galaz 2005, Gunderson and Light 2006, Robards et al. 2011), SEM can also, but not necessarily, be linked to such path dependency. In our case, through this mechanism the SEM of the Norse became part of the barrier toward adoption of a more diverse set of practices held by the Inuit SEM.

This SEM was integral to Norse governance and existed across spatial and temporal scales. It was ingrained in natural resource management applied in other parts of the Norse arctic civilization and was influential long after the decline of the Greenland settlements. Hastrup (2009) has described how farmsteads continued to be at the center of the world in the Norse selfperception between the 15 th and 19 th centuries on Iceland. Here kinsfolk continued to live according to social memory and the old and well-established ancestral order. Power and political representation were tied to landownership and agriculture, similar to the governance of the settlements on Greenland (see, e.g., Diamond 2005, Berglund 2010). However, this way of living led to a century-long decline and poverty on Iceland. When fishing started to emerge as a new pathway for well-being in the 1400 s, it was restricted, and the fishermen were thought of as part of the poverty problem because fishing tempted people to abandon the farmsteads when farm labor was most needed. Laws were passed that made farm employment compulsory. Fishing villages became illegal settlements, and fishing with more than one hook or using worms as bait was forbidden. It was not until the 19th century that fishing became the key natural resource for the Icelandic economy (Hastrup 2009).

\section{Case study 2: the Tandroy in southern Madagascar}

Androy is a rural, semiarid region situated on the south coast of Madagascar. The agropastoral Tandroy are the main group of people and have lived in the region since the 17 th century, possibly longer (Parker Pearson et al. 1996). The climate in Androy in southern Madagascar is dry, hot, and irregular. The Tandroy are a self-defined and clan-based society, and they make up the vast majority of people in Androy, with a total population of $~ 700,000$ (INSTAT 2014). In Androy, 80\% of the population pursues agropastoralism as a pathway for well-being (CGDIS 2005). Rainfall and freshwater are the most critical resources for people in the region (Decary 1930, Frère 1958, Heurtebize 1986), and it has been forecasted that aridity will increase further with climate change (Jolly 2007). When droughts are severe and prolonged, this affects harvests and livestock and eventually leads to famine (kere) as in 1986, 1991-92, and 2006. At these times, the Tandroy engage in alternative practices such as harvesting wild fruits, selling cattle, working in the city, or participating in work-forfood programs. The region is one of the poorest in Madagascar (Dostie et al. 2002); in 2009, 4 out of 5 households were asset poor (Josserand and Mustapha 2009). A recent analysis of a future scenario with increasing aridity attributable to climate change, population growth, and continued agropastoralism as the base for well-being voiced a sense of urgency about a potentially deepening poverty trap (Kinzig et al. 2006). Although famine is a main worry, intertwined with the Tandroy SEM is pride in 
belonging to a strong people, a people who withstand famine (ondaty mahatante kere). For example, this suffering from drought is shared with the zebu cattle and the cacti, with which the Tandroy sympathize (Middleton 1997, Kaufmann 2001).

In this vulnerable region, practicing fishing would be independent of droughts and has therefore been proposed as an alternative form of subsistence (CGDIS 2005). As early as the 1920s, the colonial-era biologist George Petit reported about the economic potential in marine activities. However, he noted that only Vezo villages were situated by the ocean. The Tandroy kept their backs to the ocean, and despite the cyclical droughts, they were attached to their scorched soils and to their cattle (Petit 1929). During interviews conducted for this case study, the sea off the south coast of Madagascar was described by Tandroy clan elders to be difficult and dangerous with strong currents and open ocean. The weather is known to shift quickly. During the cyclone Ernest in southern Madagascar in January 2005, 72 fishermen disappeared along the coast of Androy (Appendix 1, informant C). However, judging from Petit's witness account, fishing has existed in Androy since the 1920s, conducted by in-migrating Tanosy and Vezo fishermen. State and nonstate actors have continuously promoted fishing along the coast of Androy, but with little success. "The Tandroy belong to a traditional and conservative culture, if you wish to change it, you need to work very hard," pointed out the director of CGDIS, the regional organization responsible for coordinating development initiatives, in an interview in 2005 (Appendix 1, informant A1).

Elders of the three, i.e., noncoastal, Tandroy clans studied explained that the ancestral ways of life that the clans followed did not know the ocean. A common response was that "we do not fish because we do not know how," and "we do not fish because we do not want to die" (Appendix 1, information G1). The way of life is defined with taboos, rules that generally state what a Tandroy of a certain clan can and cannot do. In following these rules, the living maintain a connection to the ancestors, who in turn have obligations to look after the living clan members and bring fertility and well-being (cf. Middleton 1997). Land in these parts of Androy is divided into ancestral lands that belong to the clans whose ancestors were buried in it (Tengö and von Heland 2012). In an ancestral land, the taboos and customs of that ancestry are respected by the clan as well as by foreigners and guests. The following accounts are examples of SEMs. They reside in the oral memory of the community, and it is the responsibility of the elders to keep these memories that include themes of the land, cattle, forest, rain, and agriculture. However, the SEMs say little or nothing of experiences of using the seascape. When asked to specifically address the ocean, replies were usually short: "There is nothing to be said for the ocean" (Appendix 1, informant E1). Or, "It is customary that we live in the landscape, not in the ocean. [...] I know nothing about the ocean" (Appendix 1, informant G1). Several of the elders had never been to the ocean, despite the fact that it was only $\sim 20 \mathrm{~km}$ away, a distance that people regularly walked to get to the local weekly markets. No marine foods were sold in these local markets. The ocean is a barrier where almost all Tandroy activities stop short. Only by the main landing sites in Androy do there exist some Tandroy fishermen who state that they have recently begun to fish. In these cases, the changing practices are explained by intermarriage with Vezo and Tanosy and are connected to loss of strict ancestral customs and adoption of Christianity.
To be a real Vezo, on the other hand, is to be someone who lives off the ocean. A Vezo is someone who can read the sky and predict the weather and who can look at the ocean and see where the fish are. They are the "kings of the ocean" (les grands roies de la mer). The Tandroy fear the ocean, and if they are to understand it, a Vezo woman who worked as a lobster middle-hand in Faux-Cap, the main landing site, said that "they need to be taught by the Vezo" (Appendix 1, informant B). In a study of the Vezo fishing communities, Astuti (1995) argues that like the master of a trade, you are not born "a Vezo," but "become Vezo" through the experiences and skills that are gained struggling with the sea. In Astuti's study, people of different ancestries and origins had come to the coast and gradually become Vezo by picking up and mastering the skills of a fisherman. Being Vezo in this sense was juxtaposed against "those people who live in the interior ... those people who cultivate and raise cattle" (Astuti 1995:465). Reversing this logic, interior agropastoralism was what the traditional Tandroy clans did for a living. They revered the cattle and asked the ancestors to bless the land with rain and fertility. However, "being" Tandroy is not just an agropastoral practice, it is also something intimately associated with kinship, a system based on lineage and descent in which ideas of rights and obligations in the society are recognized and followed (Stone 2000). The Tandroy divide Androy into ancestral territorial cults where ancestry has a shaping influence over the living: The land that is yours, the norms, customs, and values that you hold have been given to you by your ancestors (cf. Schoffeleers 1979, Van Binsbergen and Schoffeleers 1985). We conclude that the Tandroy and the Vezo communities have two very different sets of SEMs, that there is a strong mechanism of SEM explaining path dependency in natural resource management, and that this mechanism is part of what explains the barriers toward the practices of the other community in the SES (Table 2).

\section{DISCUSSION}

\section{An alternative mechanism between SEM and resilience}

The two case studies clearly show that in an SES there can be said to exist many specific SEMs that are not necessarily connected to one another. We view the Norse and the Thule Inuit as living in the same SES, but with the specific SEMs of their respective pathways of development. The same goes for the Tandroy and the Vezo communities in contemporary Madagascar. Neither the Norse nor the Tandroy drew on the SEM of the neighboring group in the SES, but instead continued in their own development pathway. The Norse knew of Inuit people and lived near them for hundreds of years, and the Vezo fishermen have lived next to the Tandroy in Androy at least since the 1920s. What then explains the reluctance to adopting management practices of neighboring communities? Our cases show that the natural resource use and the SEM that transmits knowledge of natural resource management through time also provides coherence in communities and reinforces social structures. SEM is integral in understanding the social mechanism that in these cases gives rise to path dependence. We suggest that SEM thereby also constitutes a barrier to drawing on other SEMs. In each of the two cases, a mechanism is at work in which SEM explains path dependency and can even be argued to be linked to social traps, i.e., being more prone to famine because of a limited range of livelihoods. This mechanism links SEM and resilience of a specific development pathway as is illustrated in Figure 2. This mechanism 
Table 2. Summary of key results from cases studied.

\begin{tabular}{|c|c|c|}
\hline $\begin{array}{l}\text { Social-ecological memory } \\
\text { (SEM) }\end{array}$ & $\begin{array}{l}\text { Norse - Inuit natural resource management on } \\
\text { Greenland }\end{array}$ & $\begin{array}{l}\text { Tandroy -Vezo natural resource management on } \\
\text { Madagascar }\end{array}$ \\
\hline \multirow[t]{2}{*}{$\begin{array}{l}\text { Knowledge, experience, } \\
\text { and practice }\end{array}$} & $\begin{array}{l}\text { Norse: } \\
\text { Development of fixed farmstead dairy } \\
\text { economies in Greenland's inner fjord ecology. } \\
\text { Rearing cattle and producing hay in Greenland's } \\
\text { marginal environment. Seasonal hunting for } \\
\text { specific species of, e.g., seal and dear. Trade, seal, } \\
\text { and whale hunt using Scandinavian style wooden } \\
\text { ships. }\end{array}$ & $\begin{array}{l}\text { Tandroy: } \\
\text { Cattle rearing under uncertain arid conditions } \\
\text { with regular droughts in agro-pastoral landscape } \\
\text { of southern Madagascar. Cultivation of drought } \\
\text { resistant crops and employment of Opuntia cacti } \\
\text { as a water and food source to people and cattle } \\
\text { during the lean season. Seasonal cattle migration } \\
\text { to find pasture. }\end{array}$ \\
\hline & $\begin{array}{l}\text { Inuit: } \\
\text { Continuous establishment of mobile settlements } \\
\text { in response to seasons, climate, and local } \\
\text { resource availability of seal, whale, and caribou. } \\
\text { Use of kayak, harpoon, and ice drill technology } \\
\text { for seal and whale hunt adapted to the Arctic } \\
\text { seascape. }\end{array}$ & $\begin{array}{l}\text { Vezo: } \\
\text { Fishing settlements along the southern coast, with } \\
\text { seasonal fishing routes and semipermanent } \\
\text { outposts in the costal zone. The use of sail } \\
\text { equipped outrigger canoes, nets, handlines, spears, } \\
\text { and masks to fish shark, lobster, conch, and fish } \\
\text { for subsistence and commercial use. }\end{array}$ \\
\hline $\begin{array}{l}\text { Community identity, coherence, } \\
\text { and differentiation to } \\
\text { neighboring communities }\end{array}$ & $\begin{array}{l}\text { The SEM of the Norse is integral to their } \\
\text { identity as dairy farmers. The Inuit SEM is } \\
\text { integral to their identity as hunters of Arctic ice } \\
\text { and sea animals. The Norse SEM differentiates } \\
\text { the Norse from the Inuit with, e.g., number of } \\
\text { cows for dairy farming regulating the societal } \\
\text { organization in the hierarchical Norse society. }\end{array}$ & $\begin{array}{l}\text { The SEM of the Tandroy is integral to the } \\
\text { ancestral clan, and their identity as pastoralists. } \\
\text { The Vezo SEM is integral to their identity as } \\
\text { fishermen and masters of the sea. The Tandroy } \\
\text { SEM differentiates the Tandroy from the Vezo } \\
\text { with, e.g., cattle being a necessary sacrifice } \\
\text { regulating the social organization in the ancestral } \\
\text { clan-society. }\end{array}$ \\
\hline $\begin{array}{l}\text { Barriers to adaptations and path } \\
\text { dependency }\end{array}$ & $\begin{array}{l}\text { The Norse SEM held knowledge of a farmstead } \\
\text { way of subsistence, clan society and political } \\
\text { organization. The member identity of a Norse } \\
\text { civilization of clans linked to land and living in } \\
\text { farmsteads made the Inuit SEM of living in } \\
\text { small groups of mobile Arctic marine animal } \\
\text { hunters seem unattractive and of little value. }\end{array}$ & $\begin{array}{l}\text { The Tandroy SEM hold knowledge of an agro- } \\
\text { pastoral way of subsistence, clan society and } \\
\text { political organization including cattle sacrifice and } \\
\text { ancestral law. The Tandroy agropastoral identity } \\
\text { and values makes the Vezo SEM of coastal living } \\
\text { and fishing as a way of life unattractive and of } \\
\text { little value. }\end{array}$ \\
\hline
\end{tabular}

is clearly different than one that links a diversity of SEMs to social-ecological resilience and sustainable pathways of development. In our two case studies, SEM takes form in relation to specific pathways because people adaptively do practices to which they attach specific meanings. SEM becomes a source of specified resilience, or robustness. It should, however, be emphasized that SEM is not the only explanatory factor for the reluctance to adopt the natural resource management practices of the neighboring community. In the Norse-Inuit case, there are clearly political and hierarchical structures that reinforce certain management practices (McGovern 1994, Diamond 2005). However, across the two cases, SEM is an integral part of the social structures and processes of the societies that explain the path dependence observed.

We recognize two important issues that offer potential critiques of these findings. First, it could be argued that because the communities studied have such different practices, ethnicity, and SEMs, they are not even living in the same SES system. However, in analogy with how it is considered key to include different stakeholders with different values and practices as part of an analysis of the resilience of contemporary SESs (Folke et al. 2005), we think the relevant SES boundary needs to be inclusive to understand social-ecological resilience. Second, is SEM the
Fig. 2. Alternative casual mechanism identified. Socialecological memory (SEM) exists as a diversity of specific SEMs, leading to a range of specified resilience. The two specific SEMs are connected to two different pathways of development of two groups within the social-ecological system (SES).

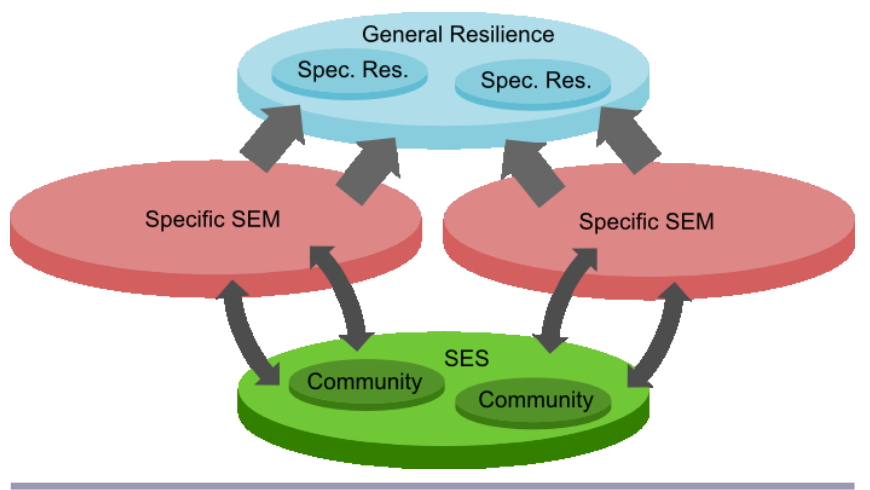


only variable that can explain this path dependency? This is not the case, and in this work, we focus on SEM because it is a concept and variable put forward in the literature on social-ecological resilience and the mechanisms to which SEM is linked. However, this does not imply that SEM is the only concept useful in understanding the mechanism between collectively learned and remembered natural resource management practices and outcomes of different forms of resilience. Indeed, other concepts that have been tied to the idea of social sources of resilience (Folke et al. 2005), such as culture and identity, social learning, or social networks, could equally well have been used. In the following discussion, we will to a limited degree relate to these.

\section{Specific SEMs, robustness, and specified resilience}

Specified resilience is related to practice and emerges in the context of deciding on a response to a specific control variable or shock. It is closely tied to questions of context and direction, i.e., resilience of what, to what? (Carpenter et al. 2001). It has also been researched as robustness (Anderies et al. 2004). Robards and colleagues (2011:524) have suggested that "distinguishing between robustness and rigidity traps is not inherently clear in resilience thinking, as a rigidity trap from one perspective can represent another's robustness." For instance, a recent robustness analysis of rice-paddy irrigation in Nepal demonstrated how institutional arrangements, in becoming robust and well tuned to cope with specific shocks, simultaneously generated vulnerabilities to novel shocks in a more general context or scale (Cifdaloz et al. 2010). This vulnerability is an inevitable consequence of managing resources under complex uncertain conditions (Anderies et al. 2004), and "society needs to choose to which uncertainties it wishes to be robust, to which uncertainties it may choose to be vulnerable, and how to focus its learning resources" (Anderies et al. 2007:15199). In our two cases, it is clear that SEM is part of what explains the robustness of a particular resource use, but the communities suffered, i.e., the Norse, and suffer, i.e., the Tandroy, from vulnerability to, for example, climatic factors. The SES in each case is resilient with respect to some factors, and with regard to the existing natural resource management practices, but not in a general sense. However, it is not widely recognized that SEM is a source of such robustness and thus linked to specified resilience. Our cases suggest that there are two mechanisms at work: one in which SEM is a source of specified resilience, as shown by our cases, and a theoretical one in which a diversity of SEMs or general SEM nurtures general resilience.

\section{General SEM and general resilience}

Resilience scholars have recently begun to distinguish between specified and general resilience (Walker and Salt 2006, Folke et al. 2010). We also find that one needs to separate between specific SEM and general SEM. General SEM then would be a source of general resilience because it provides experiences of many and different pathways that can be experimented with and drawn upon in the face of change and uncertainty, spurring renewal, novelty, and innovation (Gunderson and Holling 2002). To get at general SEM, i.e., the sum of all memories of an SES (Fig. 2), it is necessary to draw from this diversity of SEMs that, in an abstract sense, exists in the SES. However, in the two cases we examined, the groups of people held their own specific SEMs and did not recognize the diversity of SEMs and their value. Instead, they continued to build specified resilience (Fig. 2). This view of SEM as a social source resonates well with Wenger's (1998) theory of social learning in communities of practice, in which learning in communities builds structures that are both perturbable and highly resilient to change.

The cases also illustrate that it is not evident that a diversity of SEM automatically leads to general resilience. Our results show primarily how SEM in communities builds specified resilience. Specific SEM is in both cases part of what explains resistance to adopting a more diverse set of practices. This phenomenon can also be explained by other analytical tools, such as that of a dwelling perspective (Pálsson 1994). In this literature, knowledge and memory come about in lived social and ecological surroundings and are related to the community identity (Ingold 2000, Davidson-Hunt and Berkes 2003b). The SEMs of the Norse and the Tandroy both relate to a pathway as farmers, but also to a social order in which kin groups control land, economy, and law. Similarly, the SEMs of fishing and hunting among the Vezo and the Inuit relate to a different pathway and social order. To adopt practices from other people using their SEMs involves not only altered natural resource management, but also social and economic organization, thereby redefining the identity of oneself and the community. In our two cases, rather than look for similarities and opportunities, the community members actively defined themselves as different: To be Tandroy is to value an SEM that the Vezo do not.

Finally, future studies of the distinction between general and specific SEM need to be attuned to the scales of the SES studied. In both of our case studies, the SEMs are held within communities that travel and operate at the same scale, i.e., in the same arctic region in the first case, and live closely by each other, i.e., within only tens of kilometers between the communities in Androy. However, it is quite possible that general SEM can only be argued to emerge as an effect when larger scales are studied, and such cases need to critically reflect on the importance of scale.

\section{CONCLUSION}

SEM has been defined as the accumulated experience and history of ecosystem management collectively held by a community in an SES. SEM is thereby a source of adaptive capacity for renewal and reorganization that nurtures social-ecological resilience (Adger et al. 2005, Folke et al. 2005, Barthel et al. 2010), or general resilience (Folke et al. 2010). However, the case studies we have presented show that these two concepts (SEM and socialecological resilience) are not necessarily congruent. A diversity of SEM in an SES does not necessarily lead to general resilience because communities do not necessarily use the full range of SEM existing in the SES in which they reside.

In explanation, and to refine theory on the importance of SEM in SESs, we suggest a need to distinguish between specific and general SEM in SESs. Specific SEM emerges as groups manage along specific pathways of development with intended outcomes, such as cultivation among the Tandroy and the Norse or fishing and whaling among the Vezo and the Inuit. A mechanism thereby exists by which this SEM causes specified resilience. General SEM is the diversity of such specific SEMs that exist in an SES, and it is general SEM that needs to be in place to build general resilience (Folke et al. 2010). We find that it is difficult for managers to go beyond the specific SEM of the pathway of which they are a part. It should be highlighted that the difficulty is to some degree a matter of difficulty of managing cross-scale interactions. 
We propose that to change the dynamics of development pathways that do not produce desired results, it is necessary to look beyond specified resilience, and to do so, we need to improve our understanding of how specific SEM forms and how it is linked to a set of diverse SEMs. Such general SEM is intimately connected to specific SEMs from different natural resource management communities, and not only the value of a single set of memories in a specific community. The challenge lies in the interplay between the specific and the general. In this critical work, it is important to recognize that the valued diversity of SEM necessary for social-ecological resilience might actually reside in several different communities of practice.

Responses to this article can be read online at: http://www.ecologyandsociety.org/issues/responses. $\mathrm{php} / 6167$

\section{Acknowledgments:}

We would like to thank Carl Folke, Victor Galaz, Måns Nilsson, Stephan Barthel, Henrik Ernstson, and Lisen Schultz for comments on earlier versions of this manuscript. The work has been financially supported by EKOKLIM and additional projects funded by Formas, the Swedish Research Council for the Environment, Agricultural Sciences, and Spatial Planning.

\section{LITERATURE CITED}

Adger, W. N. 2006. Vulnerability. Global Environmental Change 16:268-281.

Adger, W. N., T. P. Hughes, C. Folke, S. R. Carpenter, and J. Rockström. 2005. Social-ecological resilience to coastal disasters. Science 309:1036-1039. http://dx.doi.org/10.1126/science.1112122

Allison, H. E., and R. J. Hobbs. 2004. Resilience, adaptive capacity, and the "Lock-in Trap" of the Western Australian agricultural region. Ecology and Society 9(1): 3. [online] URL: http://www.ecologyandsociety.org/vo19/iss1/art3/

Anderies, J. M., M. A. Janssen, and E. Ostrom. 2004. A framework to analyze the robustness of social-ecological systems from an institutional perspective. Ecology and Society 9(1): 18. [online] URL: http://www.ecologyandsociety.org/vol9/iss1/art18/

Anderies, J. M., A. A. Rodriguez, M. A. Janssen, and O. Cifdaloz. 2007. Panaceas, uncertainty, and the robust control framework in sustainability science. Proceedings of the National Academy of Sciences of the United States of America 104:15194-15199. http:// dx.doi.org/10.1073/pnas.0702655104

Armitage, D. R., R. Plummer, F. Berkes, R. I. Arthur, A. T. Charles, I. J. Davidson-Hunt, A. P. Diduck, N. C. Doubleday, D. S. Johnson, M. Marschke, P. McConney, E. W. Pinkerton, and E. K. Wollenberg. 2009. Adaptive co-management for socialecological complexity. Frontiers in Ecology and the Environment 7:95-102. http://dx.doi.org/10.1890/070089

Astuti, R. 1995. "The Vezo are not a kind of people": identity, difference, and "ethnicity" among a fishing people of western Madagascar. American Ethnologist 22:464-482. http://dx.doi. org/10.1525/ae.1995.22.3.02a00010
Bandura, A. 1977. Social learning theory. Prentice Hall, Englewoods Cliffs, New Jersey, USA.

Barthel, S. 2008. Recalling urban nature: linking city people to ecosystem services. Dissertation. Stockholm University, Stockholm, Sweden.

Barthel, S., J. Colding, T. Elmqvist, and C. Folke. 2005. History and local management of a biodiversity-rich, urban cultural landscape. Ecology and Society 10(2): 10. [online] URL: http:// www.ecologyandsociety.org/vol10/iss2/art10/

Barthel, S., C. Folke, and J. Colding. 2010. Social-ecological memory in urban gardens-retaining the capacity for management of ecosystem services. Global Environmental Change 20:255-265. http://dx.doi.org/10.1016/j.gloenvcha.2010.01.001

Berglund, J. 2010. Did the medieval Norse society in Greenland really fail? Pages 45-70 in P. A. McAnany and N. Yoffee, editors. Questioning collapse: human resilience, ecological vulnerability, and the aftermath of empire. Cambridge University Press, Cambridge, UK.

Berkes, F. 1998. Indigenous knowledge and resource management systems in the Canadian subarctic. Pages 98-128 in F. Berkes and C. Folke, editors. Linking social and ecological systems: management practices and social mechanisms for building resilience. Cambridge University Press, Cambridge, UK.

Berkes, F., and C. S. Seixas. 2005. Building resilience in lagoon social-ecological systems: a local-level perspective. Ecosystems 8:967-974. http://dx.doi.org/10.1007/s10021-005-0140-4

Blom, I. 1973. Kampen om Eirik Raudes land: Pressgruppepolitikk i gronlandssporsmalet 1921-1931. Gyldendal, Oslo, Norway.

Buckland, P. C., T. Amorosi, L. K. Barlow, A. L. Dugmore, P. A. Mayewski, T. H. McGovern, A. E. J. Ogilvie, J. P. Sadler, and P. Skidmore. 1996. Bioarchaeological and climatological evidence for the fate of Norse farmers in medieval Greenland. Antiquity 70:88-96.

Carpenter, S., B. Walker, J. M. Anderies, and N. Abel. 2001. From metaphor to measurement: resilience of what to what? Ecosystems 4:765-781. http://dx.doi.org/10.1007/s10021-001-0045-9

Cifdaloz, O., A. Regmi, J. M. Anderies, and A. A. Rodriguez. 2010. Robustness, vulnerability, and adaptive capacity in smallscale social-ecological systems: the Pumpa Irrigation system in Nepal. Ecology and Society 15(3): 39. [online] URL: http://www. ecologyandsociety.org/vol15/iss3/art39/

Commissariat Général au Développement Intégré du Sud (CGDIS). 2005. Plan Régional de Développement de l'Androy. Ambovombe, Madagascar.

Costanza, R. 1987. Social traps and environmental policy. BioScience 37:407-412. http://dx.doi.org/10.2307/1310564

Davidson-Hunt, I., and F. Berkes. 2003a. Learning as you journey: Anishinaabe perception of social-ecological environments and adaptive learning. Conservation Ecology 8(1): 5. [online] URL: http://www.consecol.org/vol8/iss1/art5/

Davidson-Hunt, I., and F. Berkes. 2003b. Nature and society through the lens of resilience: toward a human-in-ecosystem perspective. Pages 53-82 in F. Berkes, J. Colding, and C. Folke, editors. Navigating social-ecological systems: building resilience 
for complexity and change. Cambridge University Press, Cambridge, UK.

Decary, R. 1930. L'Androy (extrême sud de Madagascar): Essai de monographie régionale. Société d'éditions géographiques, maritimes et coloniales, Paris, France.

Diamond, J. 2005. Collapse. How societies choose to fail or succeed. Viking, New York, New York, USA.

Dietz, T., E. Ostrom, and P. C. Stern. 2003. The struggle to govern the commons. Science 302:1907-1912. http://dx.doi.org/10.1126/ science. 1091015

Dostie, B., S. Haggblade, and J. Randriamamonjy. 2002. Seasonal poverty in Madagascar: magnitude and solutions. Food Policy 27:493-518. http://dx.doi.org/10.1016/S0306-9192(02)00063-5

Dugmore, A. J., C. Keller, and T. H. McGovern. 2007. Norse Greenland settlement: reflections on climate change, trade, and the contrasting fates of human settlements in the North Atlantic islands. Arctic Anthropology 44:12-36. http://dx.doi.org/10.1353/ arc. 2011.0038

Elmqvist, T., C. Folke, M. Nyström, G. Peterson, J. Bengtsson, B. Walker, and J. Norberg. 2003. Response diversity, ecosystem change, and resilience. Frontiers in Ecology and the Environment 1:488-494. http://dx.doi.org/10.1890/1540-9295(2003)001[0488: RDECAR]2.0.CO;2

Elmqvist, T., M. Pyykönen, M. Tengö, F. Rakotondrasoa, E. Rabakonandrianina, and C. Radimilahy. 2007. Patterns of loss and regeneration of tropical dry forest in Madagascar: the social institutional context. PLOS ONE 2(5):e402. http://dx.doi. org/10.1371/journal.pone.0000402

Fabricius, C., C. Folke, G. Cundill, and L. Schultz. 2007. Powerless spectators, coping actors, and adaptive co-managers: a synthesis of the role of communities in ecosystem management. Ecology and Society 12(1): 29. [online] URL: http://www.ecologyandsociety. org/vol12/iss1/art29/

Fee, S. 2000. Enga: further descriptive notes on Tandroy funerary prestations. Pages 523-550 in C. Allibert and N. Rajaonarimanana, editors. L'extraordinaire et le quotidien. Karthala, Paris, France.

Folke, C. 2006. Resilience: the emergence of a perspective for social-ecological systems analyses. Global Environmental Change 16:253-267. http://dx.doi.org/10.1016/j.gloenvcha.2006.04.002

Folke, C., S. R. Carpenter, B. Walker, M. Scheffer, T. Chapin, and J. Rockström. 2010. Resilience thinking: integrating resilience, adaptability and transformability. Ecology and Society 15(4): 20. [online] URL: http://www.ecologyandsociety.org/vol15/iss4/ $\underline{\operatorname{art} 20 /}$

Folke, C., J. Colding, and F. Berkes. 2003. Synthesis: building resilience and adaptive capacity in social-ecological systems. Pages 352-387 in F. Berkes, J. Colding, and C. Folke, editors. Navigating social-ecological systems: building resilience for complexity and change. Cambridge University Press, Cambridge, UK. http://dx.doi.org/10.1017/CBO9780511541957.020

Folke, C., T. Hahn, P. Olsson, and J. Norberg. 2005. Adaptive governance of social-ecological systems. Annual Review of Environment and Resources 30:441-473. http://dx.doi.org/10.1146/ annurev.energy.30.050504.144511
Frère, S. 1958. Panorama de l'Androy. Aframpe, Paris, France.

Galaz, V. 2005. Social-ecological resilience and social conflict: institutions and strategic adaptation in Swedish water management. $A M B I O 34: 567-572$. http://dx.doi. org/10.1579/0044-7447-34.7.567

Galaz, V., P. Olsson, T. Hahn, C. Folke, and U. Svedin. 2008. The problem of fit among biophysical systems, environmental and resource regimes, and broader governance systems: insights and emerging challenges. Pages 147-186 in O. R. Young, L. A. King, and $\mathrm{H}$. Schroeder, editors. Institutions and environmental change: principal findings, applications and research frontiers. MIT Press, Cambridge, Massachusetts, USA.

Gauthier, E., V. Bichet, C. Massa, C. Petit, B. Vannière, and H. Richard. 2010. Pollen and non-pollen palynomorph evidence of medieval farming activities in southwestern Greenland. Vegetation History and Archaeobotany 19:427-438. http://dx.doi. org/10.1007/s00334-010-0251-5

George, A. L., and A. Bennett. 2005. Case studies and theory development in the social sciences. MIT Press, Cambridge, Massachusetts, USA.

Golding, K. A., I. A. Simpson, J. E. Schofield, and K. J. Edwards. 2011. Norse-Inuit interaction and landscape change in southern Greenland? A geochronological, pedological, and palynological investigation. Geoarchaeology 26:315-345. http://dx.doi.org/10.1002/ gea. 20351

Gulløv, H. C. 2008. The nature of contact between native Greenlanders and Norse. Journal of the North Atlantic 1:16-24. http://dx.doi.org/10.3721/070425

Gunderson, L. H., and C. S. Holling. 2002. Panarchy: understanding transformations in human and natural systems. Island, Washington, D.C., USA.

Gunderson, L. H., C. S. Holling, and S. S. Light. 1995. Barriers and bridges to the renewal of regional ecosystems. Columbia University Press, New York, New York, USA.

Gunderson, L., and S. S. Light. 2006. Adaptive management and adaptive governance in the Everglades ecosystem. Policy Sciences 39:323-334. http://dx.doi.org/10.1007/s11077-006-9027-2

Hahn, T., L. Schultz, C. Folke, and P. Olsson. 2008. Social networks as sources of resilience in social-ecological systems. Pages 119-148 in J. Norberg and G. S. Cumming, editors. Complexity theory for a sustainable future. Columbia University Press, New York, New York, USA.

Hastrup, K. 2009. Destinies and decisions: taking the life-world seriously in environmental history. Pages 331-349 in S. Sörlin and P. Warde, editors. Nature's end: history and the environment. Palgrave Macmillan, Hampshire, UK.

Hedström, P., and R. Swedberg. 1998. Social mechanisms: an introductory essay. Pages 1-31 in P. Hedström and R. Swedberg, editors. Socialmechanisms: an analytical approach to social theory. Cambridge University Press, Cambridge, UK. http://dx.doi. org/10.1017/CBO9780511663901.001

Hedström, P., and P. Ylikoski. 2010. Causal mechanisms in the social sciences. Annual Review of Sociology 36:49-67. http://dx. doi.org/10.1146/annurev.soc.012809.102632 
Heurtebize, G. 1986. Histoire des Afomarolahy: clan Tandroy, extrême-Sud de Madagascar. Centre de documentation et de recherche sur l'Asie du Sud-Est et le monde insulindien (CNRS), Paris, France.

Ingold, T. 2000. The perception of the environment: essays on livelihood, dwelling and skill. Routledge, London, UK. http://dx. doi.org/10.4324/9780203466025

Institut National de la Statistique (INSTAT). 2014. Population \& démographie. INSTAT Madagascar. [online] URL: http://www. instat.mg/index.php?option $=$ com content\&view $=$ article $\&$ id $=33 \&$ Itemid $=56$

Jolly, A. 2007. An archipelago on an island: past and future of the Malagasy fauna. Lecture at the conference Society, Natural Resources \& Development in Madagascar (30-31 March 2007). University of East Anglia, Norwich, UK.

Josserand, H., and D. Mustapha. 2009. FAO/WFP crop and food security assessment mission to Madagascar. Special Report, Food and Agricultural Organization of the United Nations and World Food Programme, Rome, Italy.

Kates, R. W., W. C. Clark, R. Corell, J. M. Hall, C. C. Jaeger, I. Lowe, J. J. McCarthy, H. J. Schellnhuber, B. Bolin, N. M. Dickson, S. Faucheux, G. C. Gallopin, A. Grübler, B. Huntley, J. Jäger, N. S. Jodha, R. E. Kasperson, A. Mabogunje, P. Matson, H. Mooney, B. Moore, III, T. O'Riordan, and U. Svedin. 2001. Sustainability science. Science 292:641-642. http://dx.doi.org/10.1126/science.1059386

Kaufmann, J. C. 2001. La Question des Raketa: colonial struggles with prickly pear cactus in southern Madagascar, 1900-1923. Ethnohistory 48:87-121. http://dx.doi.org/10.1215/00141801-48-1-2-87

Kinzig, A. P., P. Ryan, M. Etienne, H. Allison, T. Elmqvist, and B. H. Walker. 2006. Resilience and regime shifts: assessing cascading effects. Ecology and Society 11(1): 20. [online] URL: http://www.ecologyandsociety.org/vol11/iss1/art20/

Lofland, J., and L. Lofland. 1984. Analysing social settings. Wadsworth, Belmont, California, USA.

McGhee, R. 1984. Contact between native North Americans and the medieval Norse: a review of the evidence. American Antiquity 49:4-26. http://dx.doi.org/10.2307/280509

McGovern, T. H. 1979. The paleoeconomy of Norse Greenland: adaptation and extinction in a tightly bounded ecosystem. Columbia University Press, New York, New York, USA.

McGovern, T. H. 1980. Cows, harp seals, and churchbells: adaptation and extinction in Norse Greenland. Human Ecology 8:245-275. http://dx.doi.org/10.1007/BF01561026

McGovern, T. H. 1990. The archeology of the Norse North Atlantic. Annual Review of Anthropology 19:331-351. http://dx. doi.org/10.1146/annurev.an.19.100190.001555

McGovern, T. H. 1994. Management for extinction in Norse Greenland. Pages 127-154 in C. L. Crumley, editor. Historical ecology: cultural knowledge and changing landscapes. School of American Research, Santa Fe, New Mexico, USA.

Middleton, K. 1997. Circumcision, death, and strangers. Journal of Religion in Africa 27:341-373. http://dx. doi.org/10.1163/157006697X00199
Norberg, J., and G. S Cumming, editors. 2008. Complexity theory for a sustainable future. Columbia University Press, New York, New York, USA.

Olson, J. E., editor. 1906. The saga of Erik the Red. Pages 14-44 in J. E. Olson and E. G. Bourne, editors. The Northmen, Columbus and Cabot, 985-1503: the voyages of the Northmen; the voyages of Columbus and of John Cabot. Charles Scribner's Sons, New York, New York, USA. [online] URL: http://www.americanjourneys. org/pdf/AJ-056.pdf

Olsson, P., C. Folke, and F. Berkes. 2004. Adaptive comanagement for building resilience in social-ecological systems. Environmental Management 34:75-90. http://dx.doi.org/10.1007/s00267-003-0101-7

Pálsson, G. 1994. Enskilment at sea. Man 29:901-927. http://dx. doi.org/10.2307/3033974

Parker Pearson, M., M. K. Godden, R. Ramilisonina, and J. L. Schwenninger. 1996. The early Antandroy kingdom: excavations and survey in Androy. Nyame Akuma 45:60-64.

Perdikaris, S., and T. H. McGovern. 2008. Codfish and kings, seals and subsistence: Norse marine resource use in the North Atlantic. Pages 187-214 in T. C. Rick and J. M. Erlandson, editors. Human impacts on ancient marine ecosystems: a global perspective. University of California Press, Berkeley, California, USA.

Petit, G. 1929. Faune des colonies francaises. Bibliothèque nationale de France, Paris, France.

Pringle, H. 1997. Death in Norse Greenland. Science 275:924-926. http://dx.doi.org/10.1126/science.275.5302.924

Robards, M. D., M. L. Schoon, C. L. Meek, and N. L. Engle. 2011. The importance of social drivers in the resilient provision of ecosystem services. Global Environmental Change 21:522-529. http://dx.doi.org/10.1016/j.gloenvcha.2010.12.004

Scheffer, M. 2009. Critical transitions in nature and society. Princeton University Press, Princeton, New Jersey, USA

Scheffer, M., S. Carpenter, J. A. Foley, C. Folke, and B. Walker. 2001. Catastrophic shifts in ecosystems. Nature 413:591-596. http://dx.doi.org/10.1038/35098000

Scheffer, M., and F. R. Westley. 2007. The evolutionary basis of rigidity: locks in cells, minds, and society. Ecology and Society 12 (2): 36. [online] URL: http://www.ecologyandsociety.org/vol12/ iss $2 / \operatorname{art} 36 /$

Schoffeleers, J. M. 1979. Guardians of the land: essays on Central African territorial cults. Kachere Series, Gweru, Zimbabwe.

Stone, L. S. 2000. Kinship and gender: an introduction. Westview, Boulder, Colorado, USA.

Tengö, M., K. Johansson, F. Rakotondrasoa, J. Lundberg, J.-A. Andriamaherilala, J.-A. Rakotoarisoa, and T. Elmqvist. 2007. Taboos and forest governance: informal protection of hot spot dry forest in southern Madagascar. AMBIO 36:683-691. http:// dx.doi.org/10.1579/0044-7447(2007)36[683:TAFGIP]2.0.CO;2

Tengö, M., and J. von Heland. 2012. Adaptive capacity of local indigenous institutions: the case of the taboo forests of southern Madagascar. Pages 37-74 in E. Boyd and C. Folke, editors. Adapting institutions: governance, complexity and social- 
ecological resilience. Cambridge University Press, Cambridge, UK. http://dx.doi.org/10.1017/CBO9781139017237.006

Tidball, K. G., M. E. Krasny, E. Svendsen, L. Campbell, and K. Helphand. 2010. Stewardship, learning, and memory in disaster resilience. Environmental Education Research 16(5-6):591-609. http://dx.doi.org/10.1080/13504622.2010.505437

Utterström, G. 1955. Climate fluctuations and population problems in early modern history. Scandinavian Economic History Review 3:3-47. http://dx.doi.org/10.1080/03585522.1955.10411467

Vail, B. J. 1998. Human ecological perspectives on Norse settlement in the North Atlantic. Scandinavian Studies 70:293-312.

Van Binsbergen, W., and M. Schoffeleers. 1985. Theoretical explorations in African religion. Monographs from the African Studies Centre. KPI, London, UK.

von Heland, J. 2011. Rowing social-ecological systems: morals, culture and resilience. Dissertation. Stockholm University, Stockholm, Sweden.

von Heland, J., and C. Folke. 2014. A social contract with the ancestors-culture and ecosystem services in southern Madagascar. Global Environmental Change 24:251-264. http://dx. doi.org/10.1016/j.gloenvcha.2013.11.003

Walker, B. H., and D. Salt. 2006. Resilience thinking: sustaining ecosystems and people in a changing world. Island, Washington, D.C., USA.

Wenger, E. 1998. Communities of practice: learning, meaning, and identity. Cambridge University Press, Cambridge, UK. http://dx. doi.org/10.1017/CBO9780511803932 
Appendix 1: Table T1. Cited informants

\begin{tabular}{|c|c|c|c|c|c|}
\hline & Place & Informant & Type & Duration & Date \\
\hline $\mathrm{A}$ & $\begin{array}{l}\text { Programme de } \\
\text { Développement } \\
\text { Intégré de la } \\
\text { Région, CGDIS, } \\
\text { Ambovombe } \\
\text { (Androy). }\end{array}$ & $\begin{array}{l}\text { Head of office (1) and } \\
\text { strategic planner (2). }\end{array}$ & $\begin{array}{l}\text { Development } \\
\text { organization. }\end{array}$ & $\begin{array}{l}\text { Half-day } \\
\text { organizational } \\
\text { visit. Interviews } \\
(2 * 40 \text { mins). }\end{array}$ & Apr.-05 \\
\hline $\mathrm{B}$ & $\begin{array}{l}\text { Faux-Cap landing } \\
\text { site (Androy) }\end{array}$ & $\begin{array}{l}\text { Marie-Angela, key } \\
\text { informant, middle-woman } \\
\text { lobster trade (rabateur). }\end{array}$ & $\begin{array}{l}\text { Lobster and fish } \\
\text { landing site. }\end{array}$ & $\begin{array}{l}\text { Six days. Two } \\
\text { deep interviews } \\
(2 * 90 \text { mins. })\end{array}$ & $\begin{array}{l}\text { May-05 and } \\
\text { Nov-06 }\end{array}$ \\
\hline $\mathrm{C}$ & $\begin{array}{l}\text { Service régional de } \\
\text { la pêche et des } \\
\text { resources } \\
\text { halieutiques), Ft. } \\
\text { Dauphin (Anosy) }\end{array}$ & $\begin{array}{l}\text { Head of Service, Nambole } \\
\text { Alimosa Tsirike. }\end{array}$ & $\begin{array}{l}\text { Local office, } \\
\text { ministry } \\
\text { fishing. }\end{array}$ & $\begin{array}{l}\text { Half-day } \\
\text { organizational } \\
\text { visit. Interview } \\
(40 \text { mins. }) \text { and } \\
\text { statistics } \\
\text { collection. }\end{array}$ & May-05 \\
\hline $\mathrm{D}$ & Tsihombe & $\begin{array}{l}\text { School inspectors Tsihombe } \\
\text { region. }\end{array}$ & $\begin{array}{l}\text { Daily visit to } \\
\text { Faux-Cap. }\end{array}$ & $\begin{array}{l}\text { Conversation, } \\
\text { probing and story- } \\
\text { telling. }\end{array}$ & Dec-06 \\
\hline $\mathrm{E}$ & Ambonaivo village & $\begin{array}{l}\text { Male lineage elders and } \\
\text { representatives two Tandroy } \\
\text { clans and villages }(1,2,3) \text {. }\end{array}$ & $\begin{array}{l}\text { Residential field } \\
\text { site. }\end{array}$ & $\begin{array}{l}\text { Landscape oral } \\
\text { history walk, deep } \\
\text { interviews, } \\
\text { listening-and- } \\
\text { following story- } \\
\text { telling. }\end{array}$ & $\begin{array}{l}\text { (>month). } \\
\text { Mar-May 05; } \\
\text { Nov-Dec } 06\end{array}$ \\
\hline $\mathrm{F}$ & $\begin{array}{ll}\text { Southern } & \text { Androy } \\
\text { fieldwork } & \end{array}$ & $\begin{array}{l}\text { RASOLONDRAINY } \\
\text { Tanambelo Vassili } \\
\text { Reinaldo. }\end{array}$ & $\begin{array}{l}\text { University of } \\
\text { Toliara, Dept. of } \\
\text { Archaeology }\end{array}$ & Interpreter. & Nov-Dec 06 \\
\hline $\mathrm{G}$ & Sihanamaro & $\begin{array}{lll}\text { Mpisoro } & (1), & \text { assistant } \\
\text { mayor (2). } & \end{array}$ & Two day trips. & $\begin{array}{l}\text { Deep interviews, } \\
\text { participation in } \\
\text { mayor's office and } \\
\text { Hazomanga } \\
\text { meeting. }\end{array}$ & Nov.-06 \\
\hline
\end{tabular}

